Dunamis: Jurnal Teologi dan Pendidikan Kristiani

Volume 6, Nomor 1 (Oktober 2021)

ISSN 2541-3937 (print), 2541-3945 (online)

http://www.sttintheos.ac.id/e-journal/index.php/dunamis

DOI: $10.30648 /$ dun.v6i1.386

Submitted: 30 Juni 2020

Accepted: 7 Januari 2021

Published: 3 Agustus 2021

\title{
Peran Keluarga terhadap Peningkatan Spiritual Remaja pada Masa Pandemi Covid 19
}

\author{
Meyva Polii \\ Program Studi Magister Pendidikan Agama Kristen, Universitas Kristen Indonesia \\ meyvapolii91@gmail.com
}

\begin{abstract}
The world is currently facing the covid-19 pandemic which has been shifting most of human daily life by using digital technology. One that was worried about the teenagers spirituality disruption due to excessive use of digital technology. This paper aimed to study the parenetal's role in the spiritual growth of teenagers during the covid-19 pandemic through a literature study. Through this study, it was concluded that the pandemic period was an opportunity for parents to optimally implement Christian Religious Education in the family due to the large amount of meeting time between parents and teenagers at home. Thus it can be an opportunity for parents to as much as possible improve the spirituality of their teenagers.
\end{abstract}

Keywords: covid-19 pandemic; Christian Religious Education; teenagers spirituality; family; spiritual disruption

\begin{abstract}
Abstrak
Saat ini dunia tengah dihadapkan dengan fenomena pandemi covid-19 yang mengalihkan sebagian besar rutinitas manusia dengan menggunakan teknologi digital. Salah satu hal yang dikuatirkan dampaknya terhadap spiritual remaja yang akan merosot karena penyalagunaan teknologi digital secara berlebihan. Tulisan ini bertujuan untuk mengkaji peran orang tua terhadap pertumbuhan spiritual remaja pada masa pandemi covid-19 melalui studi kepustakaan. Melalui kajian ini disimpulkan bahwa masa pandemi menjadi kesempatan bagi orang tua untuk menerapkan Pendidikan Agama Kristen dalam keluarga secara optimal oleh karena banyaknya waktu pertemuan antara orang tua dan remaja di rumah. Dengan demikian hal itu dapat menjadi peluang bagi orang tua untuk semaksimal mungkin meningkatkan kerohanian anak remajanya.
\end{abstract}

Kata Kunci: pandemi covid-19; Pendidikan Agama Kristen; spiritual remaja; keluarga; disrupsi spiritual 


\section{PENDAHULUAN}

Penyebaran covid-19 yang begitu massif di seluruh dunia menyebabkan Organisasi Kesehatan Dunia (WHO) secara resmi menetapkan covid-19 sebagai pandemik. ${ }^{1}$ Dampak dari pandemi ini mengakibatkan banyak negara yang memutuskan untuk menutup sekolah-sekolah dan perguruan tinggi-perguruan tinggi. Menurut data yang diperoleh UNESCO setidaknya ada 290,5 juta siswa di seluruh dunia yang aktivitas belajarnya menjadi terganggu akibat sekolah yang ditutup. ${ }^{2}$ Demi tetap berjalannya kegiatan pendidikan, pemerintah mengambil inisiatif mendorong pembelajaran dilakukan secara online. Pada masa pandemi ini juga, di mana banyak aktivitas bergeser menjadi aktivitas online, seperti belajar dan beribadah, membawa tantangan dan ancaman bagi remaja. Muncul berbagai perila$\mathrm{ku}$ remaja yang dinilai tidak pada tempatnya, antara lain: para remaja lebih banyak meluangkan waktu untuk bermain game online daripada mengikuti kegiatan ibadah yang dilakukan secara daring. Pembelajaran dari sekolah dan ibadah dari gereja yang dilakukan secara daring menjadi alasan bagi

\footnotetext{
${ }^{1}$ Albet Saragih dan Johanes Waldes Hasugian, "Model Asuhan Keluarga Kristen di Masa Pandemi Covid-19," Teruna Bhakti 3, no. 1 (2020): 1-11, http://stakterunabhakti.ac.id/e-journal/index.php/ teruna article/view/56.

${ }^{2}$ Agus Purwanto et al., "Studi Eksploratif Dampak Pandemi COVID-19 Terhadap Proses Pembelajaran Online di Sekolah Dasar," EduPsyCouns: Journal of
}

mereka untuk menggunakan gadget terusmenerus. Tentu saja hal itu berimplikasi pada hubungan komunikasi dan kepedulian antar sesama anggota keluarga dan sesama menjadi kurang baik, serta besarnya kemungkinan para remaja terjerumus pada hal-hal yang negatif dari penggunaan media digital.

Dalam situasi pandemi ini, keluarga sebagai pendidik perlu berhikmat untuk menuntun anak-anak menuju pencapaian hidup berkualitas. ${ }^{3}$ Berdasarkan dari yang yang telah diuraikan di atas, Asmat Purba melihat pentingnya keluarga memberikan pendidikan kepada anak demi menyikapi situasi yang sedang terjadi. Kajian yang dilakukan Purba mengacu pada peran orang tua dalam keluarga untuk memberikan edukasi terkait situasi yang mengakibatkan banyak hal berubah dalam kebiasaan dan pola hidup anak. ${ }^{4}$ Sejalan dengan pandangan Purba, peneliti juga melihat bahwa saat ini Pendidikan Agama Kristen (PAK) dalam keluarga menjadi suatu kebutuhan penting untuk meningkatkan spiritual remaja. Spiritual remaja yang mengalami peningkatan akan menghasilkan moral dan karakter yang baik. Seba-

Education, Psychology and Counseling 2, no. 1 (2020): 1-12, https://ummaspul.e-journal.id/ Edupsycouns/article/view/397.

${ }^{3}$ Frans Pantan dan Priskila Issak Benyamin, "Peran Keluarga dalam Pendidikan Anak pada Masa Pandemi Covid-19," Journal of Pentecostal Theology 3, no. 1 (2020): 13-24. ${ }^{4}$ Ibid. 
liknya, jika terjadi kemerosotan pada moral dan karakter remaja pertanda terjadinya krisis spiritual di dalam keluarga. Oleh karena itu, keluarga, khususnya orang tua, memiliki peran penting dengan menjadi motivator, fasilitator, sahabat, guru, dan mentor dalam meningkatkan spiritual remaja.

\section{METODE PENELITIAN}

Penulisan ini menggunakan studi kepustakaan yang mengacu pada data atau referensi yang berkaitan dengan topik yang diangkat. Sumber data dalam penulisan ini adalah berhubungan langsung dengan gagasan PAK dan spriritual remaja. Selain itu, penulis juga merujuk pada buku-buku dan karya ilmiah yang membahas wacana PAK dalam keluarga untuk memfasilitasi pemahaman orang tua tentang peningkatan spiritual remaja pada masa pandemi covid-19.

Langkah-langkah yang dilakukan dalam penulisan ini adalah dengan terlebih dahulu menganalisis dampak pandemi covid-19 terhadap spiritual remaja. Kemudian, melakukan kajian terhadap beberapa literatur dan hasil penelitian lainnya guna memperoleh gambaran permasalahan yang sebenarnya. Selanjutnya memaparkan peran

${ }^{5}$ Christa Siahaan dan Anneke Rantung, "Peran Orang tua Sebagai Pendidik dan Pembentuk Karakter Spiritualitas Remaja," Pendidikan Agama Kristen SHANAN 3, no. 2 (2019): 95-114.

${ }^{6}$ Deslana R. Hapsarini \& Wahyu Suprihati, "Peran Orang Tua Dalam Mengembangkan Kecerdasan Spiritual Anak Di Era Masa Kini," Veritas Lux Mea orang tua dalam mengajarkan PAK sebagai solusi dalam meningkatkan spiritual remaja.

\section{HASIL DAN PEMBAHASAN}

\section{Spiritualitas Remaja}

Secara sederhana Henk Ten Napel mengartikan spiritualitas sebagai kerohanian (spirituality). Sidjabat mengemukakan spiritualitas sebagai kekuatan yang sematamata bersumber dari manusia, sebagai upaya dirinya untuk mendemonstrasikan hidup yang berarti bagi sesamanya. Spiritualitas dimengerti sebagai keterkaitan batin manusia untuk mengerti, menanggapi serta mengambil sikap dan keputusan dalam realitas dan tujuan hidup manusia. ${ }^{5}$ Spiritualitas Kristen merupakan keberadaan seseorang yang berada di dalam relasi yang benar dengan Allah, sesama, dan ciptaan yang lain. ${ }^{6}$ Chan mengartikan spiritualitas sebagai keadaan kehidupan (kepribadian) yang di dalamnya terkandung kekuatan rohani dan semangat hidup, dimana sumber daya spiritual orang Kristen adalah Yesus Kristus yang dimungkinkan melalui kehadiran dan karya Roh Kudus. ${ }^{7}$

(Jurnal Teologi dan Pendidikan Kristen) 1, no. 2 (2019): 100-118, http://jurnal.sttkn.ac.id/index.php/ Veritas/article/view/46/pdf.

${ }^{7}$ S. Matondang, "Memahami Identitas Diri Remaja dalam Kristus Menurut Efesus 2:1-10," ILLUMINATE: Jurnal Teologi dan Pendidikan Agama Kristen 1, no. 1 (2018): 105-124. 
Spiritualitas remaja merupakan suatu hubungan rohani yang dibangun dan dibentuk dalam diri seorang remaja untuk hidup dalam jalan yang benar yang bersumber dari Tuhan Yesus Kristus dalam menentukan dan mengambil keputusan tentang tujuan hidupnya. Dalam hal ini hidup remaja mulai dibimbing dengan tujuan untuk memuliakan Tuhan. Spiritualitas remaja tidak hanya dipengaruhi oleh faktor internal saja, namun ada juga pengaruh eksternal, yaitu orang-orang yang sudah bertumbuh dan dewasa, baik secara jasmani maupun rohani, untuk membimbing, mendidik, dan mengarahkannya kepada tujuan hidup yang berpedoman kepada kebenaran Tuhan Yesus melalui Alkitab.

\section{Pendidikan Agama Kristen di Keluarga}

Pada masa pandemi covid-19 ini, orang tua yang memperoleh peluang yang sangat besar dalam mendidik anak-anak, perlu menanamkan nilai-nilai Kristiani dalam kehidupan sehari-hari. ${ }^{8}$ Yesus Kristus harus menjadi sentral dari PAK dalam keluarga. Tentunya sebelum orang tua mendidik anak-anak, orang tua harus terlebih dahulu

${ }^{8}$ May Rauli Simamora dan Johanes Waldes Hasugian, "Penanaman Nilai-Nilai Kristiani bagi Ketahanan Keluarga di Era Disrupsi," Regula Fidei 5, no. 1 (2020): 13-24.

${ }^{9}$ Ruwi Hastuti, "Pendidikan Agama Kristen Dalam Keluarga Sebagai Pusat Bermisi," Jurnal Antusias 2, no. 4 (2013): 23-68.

${ }^{10}$ Herianto Sande Pailang dan Ivone Bonyadone Palar, "Membangun Spiritual Remaja Masa Kini memiliki kerohanian yang berkualitas, hikmat, kemauan dan disiplin diri untuk terus meningkatkan pertumbuhan kerohanian di dalam keluarga. Orang tua harus menjadi kesaksian yang hidup melalui dalam kehidupan sehari-hari melalui perkataan dan perbuatan. ${ }^{9}$ Dengan kata lain, apapun yang orang tua lakukan harus sejalan dengan apa yang diajarkan kepada anak-anak.

J. Vernon McGee menjelaskan ayat dari Amsal 22: 6 bahwa orang tua harus melatih seorang anak menurut jalan yang seharusnya dia tempuh. Maksudnya bahwa Allah memiliki sebuah jalan yang Dia ingin agar anak itu melakukannya atau menurutinya. Orang tua wajib menemukan jalan itu. Seorang anak tidak dituntun menurut apa yang dianggap baik oleh orang tua tetapi menurut jalan yang Allah inginkan untuk anak itu jalani dalam kehidupannya. ${ }^{10}$ Maksud Amsal 22:6 ini juga diperjelas lagi oleh Khelelufna bahwa mendidik orang muda bukanlah menurut persepsi orang muda, tetapi menurut apa yang patut bagi Tuhan. ${ }^{11}$ Selanjutnya Khoe Yao Tung menegaskan bahwa mendidik anak di dalam Tuhan adalah mendidik dalam spiritual. ${ }^{12}$ Pandangan-

Berdasarkan Amsal 22 : 6," Jurnal Jaffray 10, no. 1 (April 1, 2012): 59.

${ }^{11}$ Jusuf Haries Kelelufna, "Tidak Patut Mendidik Menurut Jalan yang Patut: Studi Eksegesis Amsal 22:6," DUNAMIS: Jurnal Teologi dan Pendidikan Kristiani 5, no. 1 (2020): 18-36.

${ }^{12}$ Ezra Tari dan Talizaro Tafonao, "Tinjauan Teologis-Sosiologis terhadap Pergaulan Bebas Remaja," Dunamis: Jurnal Teologi dan Pendidikan 
pandangan ini jelas menunjukkan bahwa mendidik remaja harus di dalam Tuhan dengan menanamkan nilai-nilai kebenaran Alkitab sebagai kunci utama agar spiritualitas remaja masa kini dapat bertumbuh.

Pendidikan dimulai dari keluarga. Pada masa pandemi ini, keluarga bahkan merupakan tempat pertama dan memiliki peran yang sangat penting bagi peningkatan spiritualitas dengan mengajarkan PAK kepada anak-anak, khususnya remaja. Ada beberapa hal yang perlu diperhatikan oleh orang tua dalam pengajaran PAK di rumah. Pertama, orang tua harus terlebih dahulu memberikan suasana hidup keluarga yang nyaman bagi remaja, yaitu dengan menciptakan hubungan berkeluarga yang harmonis, yang di dalamnya ada saling pengertian, terbuka, menjaga, menghargai dan saling memenuhi kebutuhan. Dengan demikian, terbentuklah hubungan yang baik antara orang tua dan anak serta memungkinkan kegiatan pendidikan dapat dilaksanakan dengan efektif. ${ }^{13}$ Kedua, orang tua harus menjadi pendidik di dalam keluarga. ${ }^{14}$ Masa re-

Kristiani 3, no. 2 (2019): 199-211, https:// sttintheos.ac.id/e-journal/index.php/dunamis/article/ view/181.

${ }^{13}$ Farida Yunistiati et al., "Keharmonisan Keluarga, Konsep Diri dan Interaksi Sosial Remaja," Persona:Jurnal Psikologi Indonesia 3, no. 01 (2014).

${ }^{14}$ Herianto Sande Pailang dan Ivone Bonyadone Palar, "Membangun Spiritual Remaja Masa Kini Berdasarkan Amsal 22 : 6," Jurnal Jaffray 10, no. 1 (2012): 59.

${ }^{15}$ Kavolder Togatorop, "Pengaruh Peningkatan Ibadah dalam Keluarga Terhadap Karakter Remaja maja adalah masa yang sangat penting dalam pencarian jati dirinya. ${ }^{15}$ Pada masa ini juga anak remaja mulai mengenal pergaulan yang lebih luas dibanding dengan masa kanak-kanak, ingin mencoba hal baru dan mudah untuk dipengaruhi, ${ }^{16}$ sehingga lebih rentan untuk terjerumus pada hal-hal negatif. ${ }^{17}$ Oleh karena itu, orang tua harus mendidik remaja untuk bijak dalam menggunakan media digital pada masa pendemi ini. Ketiga, orang tua harus memiliki komitmen dan selalu menjalankannya dengan konsisten. Orang tua harus memiliki komitmen bersama untuk mendidik anak-anaknya. Nilai-nilai spiritual harus sudah mulai terpupuk sebagai wujud dari didikkan yang ada di dalam keluarga. Komitmen yang dimaksud disini adalah bagaimana orang tua memegang teguh pengajaran yang diberikan. Sehingga ketika remaja melakukan kesalahan atau ada sesuatu mulai menyeleweng, orang tua dapat dengan tegas menyatakan, meluruskan dan mengarahkan kembali pada nilai-nilai spiritual yang benar. Untuk itu, orang tua harus mengajarkan

Kristen di Yayasan Perguruan Anugerah Sinagoge SMPTK Medan," PROVIDENSI: Jurnal Pendidikan dan Teologi 3, no. 1 (2020): 52-66, http://repositorio.unan.edu.ni/2986/1/5624.pdf.

${ }^{16}$ Khamim Zarkasih Saputro, "Memahami Ciri dan Tugas Perkembangan Masa Remaja," Aplikasia: Jurnal Aplikasi Ilmu-ilmu Agama 17, no. 1 (2018): 25.

${ }^{17}$ Dadan Sumara, Sahadi Humaedi, dan Meilanny Budiarti Santoso, "Kenakalan Remaja Dan Penanganannya," Prosiding Penelitian dan Pengabdian kepada Masyarakat 4, no. 2 (2017). 
anak untuk hidup dalam kebenaran firman Tuhan agar menjadi pedoman bagi remaja untuk sadar dari kesalahannya dan memperbaikinya ke arah yang benar.

\section{Orang Tua sebagai Teladan}

Pada masa pandemik ini, orang tua berperan sebagai guru yang membimbing remaja belajar di rumah. Namun, peran orang tua sebagai guru tidak terbatas pada memberikan pengajaran tentang ilmu pengetahuan. Orang tua berperan sebagai pengajar dan pembimbing remaja untuk bertumbuh secara spritual di dalam Kristus melalui pengajaran PAK dalam keluarga. Pengajaran tentang Yesus tidak hanya sebatas pada ranah kognitif namun juga harus secara afektif yakni mengenal dan menerima Tuhan Yesus, serta ranah psikomotorik yang mampu menerapkan Firman Tuhan di dalam kehidupan sehari-hari.

Sebagaimana sudah dijelaskan sebelumnya, Harianto GP juga berpendapat bahwa orang tua memegang tanggung jawab utama dalam keluarga dan anggota keluarga lainnya hanya membantu dan sebagai pelengkap. ${ }^{18}$ Orang tua sebagai guru bertanggung jawab memberi teladan dan mendidik remaja dalam kasih dan ajaran Tuhan (Ef. 6:4), serta dapat menerima segala keadaan

18 Siahaan dan Rantung, "Peran Orang tua Sebagai Pendidik dan Pembentuk Karakter Spiritualitas Remaja."

19 Ibid. mereka. Dengan demikian orang tua perlu mengambil sikap tegas dalam mengajarkan dan mendisiplinkan anak (bnd. 1 Sam. 2:1126 tentang kisah anak Eli), memiliki ketekunan (Ul. 6:6-9), serta harus konsisten dalam pengajaran itu. Perilaku yang ditunjukkan oleh anak remaja merupakan cerminan dari kualitas pendidikan yang orang tua berikan. ${ }^{19}$

Pada masa pandemi orang tua akan menghabiskan waktu sebagian besar dengan mengerjakan segala sesuatu bersama anak. Dalam keseharian tanpa disadari anak akan menuntut suatu keteladan orang tua mulai dari saat bekerja, mengajar sampai pada saat beribadah. Anak akan sangat memperhatikan bagaimana orang tuanya mempergunakan waktu dan mengerjakan sesuatu dengan bijak, hingga bagaimana sikap dalam mengikuti ibadah sekalipun hanya dilakukan dengan cara daring. Keteladanan yang ditunjukkan oleh orang tua lebih berpengaruh daripada beribu nasehat yang dikatakan. Orang tua harus menjadikan pribadinya sebagai teladan. Sebagaimana tercermin dalam kitab Amsal 20:7; 23:26; 13:20 yang secara verbal menggambarkan keteladanan orang tua bagi anakanak. ${ }^{20}$ Oleh karena itu, orang tua perlu be-

20 Devi Wahyu Setiawati, Fredik Melkias Boiliu, Kaleb Samalinggai, "Peran Pendidikan Agama Kristen Di Era Digital Sebagai Upaya Mengatasi Penggunaan Gadget Yang Berlebihan Pada Anak 
lajar dari teladan seorang Guru Agung yaitu Tuhan Yesus Kristus. Dalam kehidupan sehari-hari Tuhan Yesus memberikan teladan melalui perkataan, tingka laku, kasih, kesucian dan kesetiaan. ${ }^{21}$

\section{Orang Tua sebagai Pemimpin}

Di dalam keluarga, orang tua berperan sebagai pemimpin bagi anak-anaknya. Dalam pengertian yang sederhana pemimpin adalah orang yang memberi perintah kepada pengikutnya. Pemimpin adalah seorang yang memberi pengaruh terhadap komunitas masing-masing: guru di lingkungan sekolahnya, mahasiswa di lingkungan kampusnya, orang tua di dalam rumahnya dan lain sebagainya. ${ }^{22}$ Dalam kehidupan seharihari, terdapat tiga model kepemimpinan menurut Rohani, yakni: ${ }^{23}$ pertama, otoriter, yang secara harfiah berarti berkuasa sendiri atau sewenang-wenang. Dampak dari kepemimpinan seperti ini terhadap remaja akan menjadikan pribadi yang tidak mandiri, terkekang, melakukan segala sesuatu dengan baik hanya jika ada yang mengawasi dan terpaksa. Kedua, Laizzes Faire, merupakan model kepemimpinan yang menghasilkan

Dalam Keluarga Di Era Disrupsi 4.0," Jurnal DIDACGE 1, no. 1 (2020): 25-8.

${ }^{21}$ Diana Kristanti, Remi Karmiati, dan Ayang Emiyati, "Profesionalitas Yesus dalam mengajar tentang kasih," Didache: Journal Christian Education 1, no. 1 (2020): 35-48.

${ }^{22}$ John Stott, Kepemimpinan Kristen: 9 Bahan Pemahaman Alkitab untuk Pribadi dan Kelompok, remaja yang mengerjakan sesuatu hanya untuk diperhatikan oleh orang tuanya. Model kepemimpinan ini tentunya tidak produktif jika diterapkan. Ketiga, demokratis, model kepemimpinan yang lebih efektif dan produktif karena memungkinkan terjalinnya hubungan persahabatan antara orang tua dan remaja dengan dasar saling memahami dan saling mempercayai.

Model kepemimpinan demoktaris adalah yang paling tepat untuk diterapkan oleh orang tua terhadap remaja disbandingkan dengan model kepemimpinan lainnya. Berjalannya waktu dengan berbagai perkembangan zaman yang sudah masuk dalam era digital dan terjebak dalam kondisi pandemi seperti ini, tentunya remaja memerlukan pemimpin yang dinamis dan dapat menjawab kebutuhan remaja. Daft mengemukakan bahwa saat ini pemimpin yang dibutuhkan adalah pemimpin yang mampu menyesuaikan diri yaitu memimpin dengan mengedepankan hubungan dan kerjasama daripada kuasa dan kendali; rajin menyuarakan visi (pemimpin visioner) dan nilai yang dianut, kerendahan hati untuk belajar dan berubah, dan berkembang. ${ }^{24}$ Model ke-

ed. Vionatha Lengkong, 1 ed. (Surabaya: Literatur Perkantas, 2019). 5

${ }^{23}$ Nasib Tua Lumban Gaol dan Andrianus Nababan, "Kepemimpinan Guru Pendidikan Agama Kristen," Kelola: Jurnal Manajemen Pendidikan 6, no. 1 (2019): 89-96.

${ }^{24}$ Desi Sianipar, "Kepemimpinan Guru Pendidikan Agama Kristen (PAK) Di Era Industri 4.0," Prosiding Seminar dan Call For Papers 
pemimpinan yang demokratis memungkinkan terjalinnya persahabatan antara orang tua dan remaja sehingga membuatnya nyaman. Remaja akan terbuka dengan semua hal yang dialami, dipikirkan, dan yang menjadi harapannya ke depannya. Hal ini terjadi oleh karena adanya sikap yang saling memahami dan saling percaya antara satu dengan yang lainnya. Pada masa pandemi ini, model kepemiminan demokratis memberikan kepercayaan dan kebebasan kepada remaja untuk menggunakan media digital secara bijak dalam sebagian besar aktifitas remaja. Namun, kebebasan yang dimaksud di sini adalah dengan tetap perlu mendapat bimbingan dan edukasi yang baik terkait penggunaan media digital agar bisa terarah dan berfaedah.

Di era digital ini, orang tua sebagai pemimpin di dalam keluarga perlu melakukan berbagai pendekatan terhadap remaja dalam hal penggunaan media digital. Sehingga penggunaan media digital bisa dimanfaatkan dengan bijak. Ronda mengemukakan ada lima pendekatan yang bisa dilakukan oleh orang tua sebagai pemimpin di dalam keluarga, yaitu: ${ }^{25}$ (1) pendekatan spiritual yang menjadikan Firman Tuhan sebagai dasar dalam menghadapi digitalisasi. Kitab Galatia memberikan pedoman untuk

"Membangun Indonesia Di Era Revolusi 4.0" Program Pascasarjana Universitas Kristen Indonesia (2018): 167-177. menghadapi kedagingan dengan hidup oleh Roh Kudus, dipimpin oleh Roh agar dapat menghasilkan buah Roh (Gal.5:16-23). Dalam hal ini dituntut kedisiplinan rohani, penyangkalan diri dan pengendalian diri sebagai sentral utama bagi kehidupan seorang pemimpin Kristen dalam penyadaran tentang bahaya dan pemanfaatan teknologi digital saat ini; (2) pendekatan edukatif, perlu dilakukan oleh seorang pemimpin dalam hal ini orang tua, untuk membangun pedoman etika Kristen dalam menggunakan media digital sehingga dapat memberikan pemahaman yang baik tentang bermedia digital; (3) pedekatan integritas, dalam hal ini orang tua melakukan pendekatan kepada remaja agar memahami etika dalam menggunakan teknologi digital agar terhindar dari perbuatan plagiat dan tidak menggunakan media digital untuk menghujat dan menyebarkan kebencian bagi orang lain; (4) pedekatan azas manfaat, orang tua sebagai pemimpin dalam keluarga harus menggunakan perkembangan digital sebagai peluang untuk melakukan pelayanan, pemuridan dan misi. Di samping itu juga, teknologi digital dapat digunakan untuk mengembangkan diri dalam pengetahuan, pekerjaan, dan usaha; (5) pendekatan humanistik, memandang para remaja sebagai ciptaan

${ }^{25}$ Daniel Ronda, "Kepemimpinan Kristen Di Era Disrupsi Teknologi," Evangelikal: Jurnal Teologi Injili dan Pembinaan Warga Jemaat 3, no. 1 (2019): $1-8$. 
Tuhan yang harus dilayani dengan penuh kasih. Di tengah perkembangan teknologi yang tiada batas orang tua sebagai pemimpin di dalam keluarga harus memberikan kasih sayang terhadap remaja melalui perhatian, bimbingan, nasihat serta doa. Halhal tersebut merupakan kebutuhan utama dalam keluarga yang tidak tergantikan oleh kemajuan digital saat ini.

\section{Orang Tua sebagai Mentor}

Berdasarkan hasil penelitian Fitria dan Ifdil tingkat anxiety remaja 54\% berada pada kategori tinggi di saat pandemi covid19. ${ }^{26}$ Anxiety ini menggambarkan suatu kecemasan sebagai bentuk ketidakberanian dan kerisauan serta perasaan takut terhadap sesuatu hal yang kurang jelas. Anxiety cenderung dialami oleh para remaja karena usia remaja dapat digolongkan pada usia yang masih labil dalam menghadapi kondisi-kondisi yang tidak terduga. ${ }^{27}$ Kurangnya informasi tentang penanganan covid-19 dan pemberitaan tentang kian bertambah jumlah kasus positif covid-19 membuat remaja berpikir akan kemungkinan jika tertular penyakit ini, yang membawa pada kemungkinan tidak bisa sembuh dan berujung pada kematian.

\footnotetext{
${ }^{26}$ Linda Fitria dan Ifdil Ifdil, "Kecemasan Remaja pada Masa Pandemi Covid-19," Jurnal EDUCATIO: Jurnal Pendidikan Indonesia 6, no. 1 (2020): 1. ${ }^{27}$ Ibid.
}

Kondisi remaja di atas, tentu tidak bisa dibiarkan. Karena itu, peran orang tua sebagai mentor dalam perkembangan spiritual remaja pada masa pendemi sangatlah dibutuhkan. Orang tua selaku mentor dapat membimbing para remaja untuk tidak perlu kuatir dalam mengadapi berbagai kecemasan tersebut dengan cara memberikan pengetahuan tentang covid-19. Dalam kehidupan sehari-hari remaja juga perlu dibimbing agar dapat menjaga diri sebagaimana protokol kesehatan yang berlaku, serta membimbing remaja untuk tetap bertumbuh secara spiritual dengan berpedoman pada Alkitab, misalnya dengan menunjukkan adanya jaminan pemeliharaan Tuhan terhadap marabahaya sebagaimana yang terdapat dalam Mazmur 91:1-16. ${ }^{28}$

Menurut Ivone Palar, sebagai mentor remaja orang tua berperan untuk menjaga dan memelihara kehidupan remaja dari awal sehingga para remaja mengetahui jalan kebenaran melalui firman Tuhan di dalam kehidupan remaja. Dengan demikian, di masa yang akan datang para remaja akan menjadi pribadi yang kuat, berdiri kokoh dalam imannya dan takut kepada Tuhan. Kerohanian mereka pun akan mengalami pertumbuhan sehingga mereka dapat men-

\footnotetext{
${ }^{28}$ Simon, "Respon Orang Kristen Terhadap Pemberitaan Televisi Mengenai Covid-19," Jurnal Gamaliel 2, no. 2 (2020): 114-131, http://jurnal.sttgamaliel.ac.id/index.php/gamaliel/article/view/52.
} 
jadi berkat bagi sesama remaja maupun lingkungan sekitarnya. ${ }^{29}$

\section{Orang Tua sebagai Konselor}

Masa remaja merupakan masa yang paling sulit dalam perkembangan hidup manusia. Seorang psikolog bernama Stanley Hall dari Amerika menyebut masa remaja sebagai masa storm and stress, untuk menggambarkan suatu masa dalam hidup manusia yang penuh dengan gejolak dan tekanan. Begitu pula pada masa pandemi, berdasarkan hasil survei global oleh Himpunan Psikolog Indonesia pada Gugus Tugas Layanan Psikologi Covid-19, mengemukakan bahwa anak muda usia 21 tahun ke bawah cenderung mengalami tekanan lebih berat dibandingkan dengan kelompok usia yang lebih tua. ${ }^{30}$ Usia remaja yang masih labil dalam menghadapi kondisi saat ini dapat berdampak pada kerentanan sosial bagi diri remaja sendiri maupun orang lain. Dampak dari kerentanan sosial dapat membuat seseorang bertindak apatis, tindakan irasional dan tindakan kriminal. ${ }^{31}$

Masa remaja dikenal dengan masa untuk mencari teman, sahabat, dan mungkin

\footnotetext{
${ }^{29}$ Jonathan Matheus dan Elisabet Selfina, "Peran Pembina Remaja Bagi Perkembangan Perilaku Remaja Di Gereja Kemah Injil Indonesia Tanjung Selor Kalimantan Utara," Jurnal Jaffray 13, no. 1 (2015): 1-22.

${ }^{30} \mathrm{Z}$ Musyirifin, "Strategi Pengendalian Kerentanan Sosial Remaja Berbasis Bimbingan Pribadi Sosial," Prosiding Seminar Nasional Bimbingan dan Konseling Mengukuhkan Eksistensi Peran BK Pasca
}

seseorang yang memiliki hubungan istimewa. ${ }^{32}$ Pada umumnya, seseorang pada masa remaja akan lebih banyak menghabiskan waktu bersama dengan teman-temannya dibandingkan dengan keluarganya atau sendirian. ${ }^{33}$ Pada masa pandemi covid-19 ini pun tidak dapat membatasi remaja untuk tetap berhubungan dengan teman-temannya baik di sekolah, gereja, maupun di dalam berbagai komunitas pergaulannya. Remaja dapat saling berhubungan antara satu dengannya lainnya dengan menggunakan berbagai aplikasi online yang ada ada di smartphone. Dengan demikian, tidak menutup kemungkinan remaja akan memiliki masalah baik dengan dirinya sendiri maupun dengan orang lain yang berhubungan dengannya.

Berdasarkan permasalahan tersebut orang tua memiliki peran menjadi seorang konselor. Kegiatan ini dilakukan untuk menolong remaja agar dapat memecahkan dan menyelesaikan masalah yang dialaminya berdasarkan keputusan yang tentukannya. Orang tua perlu memberikan bimbingan agar remaja dapat memahami dirinya dan cara berinteraksi serta bersikap terhadap

Pandemi Covid-19 di Berbagai Setting Pendidikan (2020): 127, http://pasca.um.ac.id/conferences/ index.php/snbk/article/view/1145.

${ }^{31}$ Ibid.

${ }^{32}$ Mien R. Uno, Buku Pintar Etiket Untuk Remaja (Jakarta: PT. Gramedia Pustaka Utama, 2009), 192.

${ }^{33}$ Ahmad Susanto, Bimbingan dan Konseling di Sekolah: Konsep, Teori, dan Aplikasinya, 1 ed. (Jakarta: Prenadamedia Grup, 2018), 144. 
orang lain, sehingga hubungan remaja dengan orang lain tetap terjaga dan terjalin dengan baik. Di samping itu, nilai-nilai Kristiani untuk saling mengasihi dan menjaga kehidupan yang damai dapat terus ditumbuhkan meskipun pada masa pandemik sekalipun.

\section{Orang Tua sebagai Motivator}

Keterbatasan waktu untuk bertemu dengan teman-teman atau komunitas secara langsung membuat remaja lebih mudah mengalami kebososanan dan akhirnya akan membawa pada penggunaan media digital secara berlebihan. Hal itu kemudian dapat mengakibatkan ketergantungan pada gadget dan berpotensi menghambat prestasi remaja. Dalam kondisi seperti ini orang tua haruslah menjadi motivator bagi remaja. Orang tua dapat membimbing remaja dengan memberikan nasihat yang berdasar pada firman Tuhan sebagai penuntun dalam kehidupannya. Stephen Tong mengemukakan bahwa motivasi yang benar penginjilan dapat memberikan kekuatan yang besar pada saat yang paling melelahkan dan memberi keteguhan pada waktu yang sukar dan sukacita pada waktu kesesakan. ${ }^{34}$ Orang tua harus senantiasa memberikan pandangan-

\footnotetext{
${ }^{34}$ Kalis Stevanus, "Karya Kristus Sebagai Dasar Penginjilan di Dunia Non-Kristen," Fidei: Jurnal Teologi Sistematika dan Praktika 3, no. 1 (2020): 119, http://www.stt-tawangmangu.ac.id/e-journal/ index.php/fidei/article/view/119/pdf.

35 Fredik Melkias Boiliu dan Meyva Polii, "Peran Pendidikan Agama Kristen dalam Keluarga di Era
}

pandangan yang mengarahkan pada masa depan anak agar remaja termotivasi untuk melakukan hal-hal yang memiliki nilai-nilai spiritual. ${ }^{35}$ Dengan demikian, remaja tidak akan mudah kecewa dan menyerah ketika menghadapi situasi-situasi sulit seperti pada masa pandemi ini. Remaja sangat membutuhkan pengenalan akan Tuhan Yesus Kristus, nasihat-nasihat, dan pertolongan, agar mereka mengerti kehendak dan rencana Tuhan dalam hidupnya.

Ketika remaja mengalami berbagai masalah orang tua harus mampu memahami pergumulan dan permasalahnya agar atas dasar itu orang tua dapat memberikan pendampingan dan menghidupkan kembali semangat hidup remaja. ${ }^{36}$ Remaja tersebut dapat dibimbing untuk menemukan penyelesaiannya. Dalam percakapan antara orang tua dan remaja, terjadi percakapan yang saling membangun dan saling mendengarkan. Hal sederhana yang bisa dilakukan adalah dengan bersedia menjadi tempat curahan kesulitan dari remaja tersebut, baik dalam hal belajar maupun masalah-masalah yang dihadapinya dengan meminta remaja tersebut menceritakan kembali segala yang dialaminya.

Digital terhadap Pembentukan Spiritualitas dan Moralitas Anak," IMANUEL Jurnal Teologi dan Pendidikan Kristen 1, no. 2 (2020): 83-102.

${ }^{36}$ Esther Rela Intarti, "Peran guru pendidikan agama kristen sebagai motivator," Regula Fidei 1, no. 2 (2018): 260-272. 
Orang tua yang berperan sebagai sebagai motivator harus mampu menghidupkan kembali semangat remaja. Dalam menghadapi permasalahan remaja yang terpenting ialah hubungan kreatif dengan Allah dalam Yesus. Roh Kudus hidup di dalam setiap orang yang percaya (Roma 8:911). Peran serta Roh Kudus merupakan sumber kemampuan yang tidak terbatas. Di antara semua hal yang dikerjakan Roh yang luar biasa adalah pembaruan sifat dan sikap seseorang. Buah karya Roh Kudus tidak lain adalah pembaruan watak menuju kesehatan mental. Sifat-sifat baru itu tidak melahirkan masalah, tetapi menyelesaikannya.

\section{Orang Tua sebagai Fasilitator}

Masa remaja memiliki ciri khasnya sendiri, di antaranya yaitu ingin mencoba hal-hal baru, ${ }^{37}$ di mana seseorang mulai mempelajari banyak hal dan mengembangkan potensi-potensi yang dimilikinya. Pada masa remaja mereka juga mulai menyampaikan kebebasannya dan haknya untuk mengemukakan pendapatnya sendiri. ${ }^{38}$ Pada masa remaja seseorang juga memiliki kepercayaan diri yang besar. ${ }^{39}$ Orang tua perlu menjadikan ini sebagai saat yang tepat untuk membentuk dan memupuk spiritual remaja remaja. Orang tua bisa berangkat dari hal-hal yang disukai remaja kemudiaan me-

\footnotetext{
${ }^{37}$ Pailang dan Palar, "Membangun Spiritual Remaja Masa Kini Berdasarkan Amsal 22 : 6."
}

ngarahkannya untuk dapat menempatkan diri. Ada banyak orang tua kuatir dengan kesenangan dan pergaulan remaja, namun perlu diingat bahwa solusinya bukanlah dengan cara membatasi dan mengekangnya. Orang tua dapat berperan sebagai fasilitator untuk mendukung kegiatan-kegiatan remaja, sembari juga memberikan pemahaman kepada remaja bahwa apa yang mereka miliki adalah berasal dari Tuhan dan apa yang mereka lakukan juga bagi Tuhan. Orang tua perlu membimbing dan mengarahkan talenta yang mereka miliki untuk kemuliaan Tuhan.

Pada masa pandemi covid-19 ini, peran orang tua sebagai fasilitator sangat dibutuhkan dalam pertumbuhan spiritual remaja. Situasi pandemi ini telah menjadikan ruang gerak dalam berbagai kegiatan remaja menjadi sangat terbatas. Orang tua perlu memfasilitasi kebutuhan remaja termasuk di dalamnya kebutuhan spiritual remaja. Masa pandemi ini dapat menjadi kesempatan bagi remaja mengaplikasikan semua firman Tuhan dalam kehidupan sehari-hari. Sebagai fasilitator, orang tua perlu menyediakan dan memfasilitasi kebutuhan remaja dalam beribadah. Apabila pada situasi normal, kebutuhan tersebut biasanya dipenuhi oleh gereja, maka pada situasi pandemi ini

\footnotetext{
${ }^{38}$ Saputro, "Memahami Ciri dan Tugas Perkembangan Masa Remaja." ${ }^{39}$ Ibid.
} 
orang tua bertanggung jawab untuk memenuhi kebutuhan spiritual remaja. Ibadah yang sebelumnya diselenggarakan di gereja, sekarang dilaksanakan di rumah masingmasing, dengan orang tua sebagai pemimpin dalam ibadah. Hal ini dapat menjadi kesempatan bagi keluarga untuk mengambalikan fungsinya sebagai pusat ibadah bagi anggota-anggota keluarganya, yang sebelumnya lebih dipercayakan kepada gereja dan pemuka agama.

\section{KESIMPULAN}

Masa pandemi covid-19 memang membatasi berbagai aktivitas remaja, baik itu bersekolah, beribadah di gereja, dan juga bersosialisasi dengan teman-teman sebayanya. Mereka harus membatasi aktivitas di luar rumah. Hal itu membawa dampak negatif, seperti misalnya remaja dapat menjadi ketergantungan terhadap gadget. Namun demikian, selain menimbulkan potensi negatif, waktu yang lebih banyak berada di rumah memberikan peluang besar bagi orang tua untuk meningkatkan aspek spiritual remaja. Orang tua dapat menjalankan berbagai peran, yang mungkin tidak akan dapat dijumpai dalam satu aktivitas di luar rumah, untuk membawa anak semakin bertumbuh dalam kerohaniannya. Namun demikian, diperlukan kepekaan dan pemahaman orang tua terhadap pribadi remaja, sehingga PAK yang dijalankan dapat berlangsung dengan baik.

\section{DAFTAR PUSTAKA}

Boiliu, Fredik Melkias, dan Meyva Polii. "Peran Pendidikan Agama Kristen dalam Keluarga di Era Digital terhadap Pembentukan Spiritualitas dan Moralitas Anak." IMANUEL Jurnal Teologi dan Pendidikan Kristen 1, no. 2 (2020): 83-102.

Fitria, Linda, dan Ifdil Ifdil. "Kecemasan remaja pada masa pandemi Covid 19." Jurnal EDUCATIO: Jurnal Pendidikan Indonesia 6, no. 1 (2020): 1.

Boiliu, Fredik Melkias, Kaleb Samalinggai, Devi Wahyu Setiawati. "Peran Pendidikan Agama Kristen Di Era Digital Sebagai Upaya Mengatasi Penggunaan Gadget Yang Berlebihan Pada Anak Dalam Keluarga Di Era Disrupsi 4.0." Jurnal DIDACHE 1, no. 1 (2020): 25-8.

Hastuti, Ruwi. "Pendidikan Agama Kristen Dalam Keluarga Sebagai Pusat Bermisi." Jurnal Antusias 2, no. 4 (2013): 23-68. https://www. sttintheos.ac.id/e-journal/index.php/ antusias/article/view/23

Intarti, Esther Rela. "Peran Guru Pendidikan Agama Kristen sebagai Motivator." Regula Fidei 1, no. 2 (2018): 260-272.

Kelelufna, Jusuf Haries. "Tidak Patut Mendidik Menurut Jalan yang Patut: Studi Eksegesis Amsal 22:6." DUNAMIS: Jurnal Teologi dan Pendidikan Kristiani 5, no. 1 (2020): 18-36. https://sttintheos. ac.id/e-journal/index.php/dunamis/ article/view/310

Kristanti, Diana, Remi Karmiati, dan Ayang Emiyati. "Profesionalitas Yesus dalam mengajar tentang kasih." Didache: Journal Christian Education 1, no. 1 (2020): 35-48. 
Lumban Gaol, Nasib Tua, dan Andrianus Nababan. "Kepemimpinan Guru Pendidikan Agama Kristen." Kelola: Jurnal Manajemen Pendidikan 6, no. 1 (2019): 89-96.

Matheus, Jonathan, dan Elisabet Selfina. "Peran Pembina Remaja Bagi Perkembangan Perilaku Remaja Di Gereja Kemah Injil Indonesia Tanjung Selor Kalimantan Utara." Jurnal Jaffray 13, no. 1 (2015): 122.

Matondang, S. "Memahami Identitas Diri Remaja dalam Kristus Menurut Efesus 2:1-10." ILLUMINATE: Jurnal Teologi dan Pendidikan Agama Kristen 1, no. 1 (2018): 105124.

Musyirifin, Z. "Strategi Pengendalian Kerentanan Sosial Remaja Berbasis Bimbingan Pribadi Sosial." Prosiding Seminar Nasional Bimbingan dan Konseling Mengukuhkan Eksistensi Peran BK Pasca Pandemi Covid-19 di Berbagai Setting Pendidikan (2020): 127. http://pasca.um.ac.id/ conferences/index.php/snbk/article/ view/1145.

Pailang, Herianto Sande, dan Ivone Bonyadone Palar. "Membangun Spiritual Remaja Masa Kini Berdasarkan Amsal 22: 6." Jurnal Jaffray 10, no. 1 (2012): 59.

Pantan, Frans, dan Priskila Issak Benyamin. "Peran Keluarga dalam Pendidikan Anak pada Masa Pandemi Covid19." Journal of Pentecostal Theology 3, no. 1 (2020): 13-24.

Purwanto, Agus, Rudy Pramono, Masduki Asbari, Priyono Budi Santoso, Laksmi Mayesti Wijayanti, Chi Hyun Choi, dan Ratna Setyowati Putri. "Studi Eksploratif Dampak Pandemi COVID-19 Terhadap Proses Pembelajaran Online di Sekolah Dasar." EduPsyCouns:
Journal of Education, Psychology and Counseling 2, no. 1 (2020): 112. https://ummaspul.e-journal.id/ Edupsycouns/article/view/397.

Ronda, Daniel. "Kepemimpinan Kristen Di Era Disrupsi Teknologi." Evangelikal: Jurnal Teologi Injili dan Pembinaan Warga Jemaat 3, no. 1 (2019): 1-8.

Saputro, Khamim Zarkasih. "Memahami Ciri dan Tugas Perkembangan Masa Remaja." Aplikasia: Jurnal Aplikasi Ilmu-ilmu Agama 17, no. 1 (2018): 25.

Saragih, Albet, dan Johanes Waldes Hasugian. "Model Asuhan Keluarga Kristen di Masa Pandemi Covid19." Teruna Bhakti 3, no. 1 (2020): 1-11. http://stakterunabhakti.ac.id/ e-journal/index.php/teruna/article/ view/56.

Siahaan, Christa, dan \& Anneke Rantung. "Peran Orang tua Sebagai Pendidik dan Pembentuk Karakter Spiritualitas Remaja." Pendidikan Agama Kristen SHANAN 3, no. 2 (2019): 95-114.

Sianipar, Desi. "Kepemimpinan Guru Pendidikan Agama Kristen (PAK) Di Era Industri 4.0." Prosiding Seminar dan Call For Papers "Membangun Indonesia Di Era Revolusi 4.0” Program Pascasarjana Universitas Kristen Indonesia (2018): 167-177.

Simamora, May Rauli, dan Johanes Waldes Hasugian. "Penanaman Nilai-Nilai Kristiani bagi Ketahanan Keluarga di Era Disrupsi." Regula Fidei 5, no. 1 (2020): 13-24.

Simon. "Respon Orang Kristen Terhadap Pemberitaan Televisi Mengenai Covid-19." Jurnal Gamaliel 2, no. 2 (2020): 114-131. http://jurnal.sttgamaliel.ac.id/index.php/gamaliel/a rticle/view/52. 
Stevanus, Kalis. "Karya Kristus Sebagai Dasar Penginjilan di Dunia NonKristen." Fidei: Jurnal Teologi Sistematika dan Praktika 3, no. 1 (2020): 1-19. http://www.stttawangmangu.ac.id/e-journal/index. php/fidei/article/view/119/pdf.

Stott, John. Kepemimpinan Kristen: 9 Bahan Pemahaman Alkitab untuk Pribadi dan Kelompok. Diedit oleh Vionatha Lengkong. 1 ed. Surabaya: Literatur Perkantas, 2019.

Sumara, Dadan, Sahadi Humaedi, Dan Meilanny Budiarti Santoso. "Kenakalan Remaja Dan Penanganannya." Prosiding Penelitian dan Pengabdian kepada Masyarakat 4, no. 2 (2017).

Suprihati, Deslana R. Hapsarini \& Wahyu. "Peran Orang Tua Dalam Mengembangkan Kecerdasan Spiritual Anak Di Era Masa Kini." Veritas Lux Mea (Jurnal Teologi dan Pendidikan Kristen) 1, no. 2 (2019): 100-118. http://jurnal.sttkn. ac.id/index.php/Veritas/article/view /46/pdf.

Susanto, Ahmad. Bimbingan dan Konseling di Sekolah: Konsep, Teori, dan Aplikasinya. 1 ed. Jakarta: Prenadamedia Grup, 2018.
Tari, Ezra, dan Talizaro Tafonao. "Jurnal Teologi dan Pendidikan Kristiani Tinjauan Teologis-Sosiologis terhadap Pergaulan Bebas Remaja." Dunamis: Jurnal Teologi dan Pendidikan Kristiani 3, no. 2 (2019): 199-211. https://www. sttintheos.ac.id/e-journal/index.php/ dunamis/article/view/181

Togatorop, Kavolder. "Pengaruh Peningkatan Ibadah dalam Keluarga terhadap Karakter Remaja Kristen di Yayasan Perguruan Anugerah Sinagoge SMPTK Medan." PROVIDENSI: Jurnal Pendidikan dan Teologi 3, no. 1 (2020): 52-66. http://repositorio.unan.edu.ni/2986/ 1/5624.pdf.

Uno, Mien R. Buku Pintar Etiket Untuk Remaja. Jakarta: PT. Gramedia Pustaka Utama, 2009.

Yunistiati, Farida, M. As'ad Djalali, M. As'ad Djalali, M. As'ad Djalali, Muhammad Farid, Muhammad Farid, dan Muhammad Farid. "Keharmonisan Keluarga, Konsep Diri dan Interaksi Sosial Remaja." Persona:Jurnal Psikologi Indonesia 3, no. 01 (2014). 